\title{
Studies of Micro Plastics contamination on mussels, seawater, and sediment at Sanrobengi Island of South Sulawesi
}

\author{
Ramdha Mawaddha1, Firdaus ${ }^{2}$, Akbar Tahir ${ }^{3}$ \\ ${ }^{1}$ Environmental Management Study Program of Graduate School, University Hasanuddin 90245, Makassar, Indonesia. \\ ${ }^{2}$ Department of Chemistry, Faculty of Science, University Hasanuddin, 90245, Makassar, Indonesia. \\ ${ }^{3}$ Department of Marine Science, Faculty of Marine Science and Fisheries, University Hasanuddin, 90245, Makassar, Indonesia.
}

Correspondence Author: Akbar Tahir, Department of Marine Science, Faculty of Marine Science and Fisheries, University Hasanuddin, Indonesia. Email: akbar_tahir@mar-sci_unhas.ac.id

Received date: 30 December 2019, Accepted date: 29 January 2020, Online date: 22 February 2020

Copyright: (C) 2020 Ramdha Mawaddha et al. This is an open-access article distributed under the terms of the Creative Commons Attribution License, which permits unrestricted use, distribution, and reproduction in any medium, provided the original author and source are credited.

\begin{abstract}
Mussels are filter feeder organisms which are categorized as sessile organism. They are vulnerable to be contaminated with microplastic (MPs) in the marine environment. Mussels are the consumed commodity since they contain high protein, such as the case in Sanrobengi Island, Takalar Regency, South Sulawesi. The laboratory analysis was conducted at Marine and Fisheries Sciences Faculty and Math and Science Faculty, Universitas Hasanuddin. The goal of this study is to analyze the microplastic abundance in the mussels of Perna viridis and Mactra sp., seawater and sediment at Sanrobengi Island. This study also analyzed the types of plastic polymers found in samples with FTIR methods. Data was collected in August 2019 in the form of primary data collection using observation techniques. The research method used is the descriptive survey to find the amount, type, color, and size of polymer microplastic. Purposive random sampling technique was carried out on the species of Perna viridis and Mactra sp. with 35 individuals collected respectively. Seawater and sediment samples were collected from triplicate from 4 stations. The results showed the average abundance of MPs on $P$. viridis was $14.62 \pm 1.46$ item/individual, and for Mactra $\mathbf{s p}$. was $2.11 \pm 0.29$ item/individual. The average abundance of microplastic contaminants in seawater was 0.28 item/liter and sediment was $169.16 \mathrm{item} / \mathrm{kg}$. Meanwhile, the predominated polymer types identified on $P$. viridis and Mactra sp. was Polyethylene terephthalate (PETE) while in sediment and seawater samples was Polyurethane (PU). Mussel, seawater and sediment in Sanrobengi Island has been contaminated by MPs particles. Moreover, the contaminated mussels also can be harmful for food security and human well-being. The high level of contamination found in mussels can be defined as the sign to conducting an immediate effort in a proper plastic waste management in Sanrobengi Island.
\end{abstract}

Keywords: microplastic, $P$. viridis, Mactra sp., sediment, seawater

\section{INTRODUCTION}

Demand for practical and consumptive lifestyles has encouraged increasing use of plastic each year. It consequently, has produced a significant amount of waste [1]. Plastic has a negative impact since it is persistent in the environment and not biodegradable. The plastic has the potential to cause pollution in the form of microplastic due to the fragmentation process into smaller pieces of less than $5 \mathrm{~mm}$ [2]. All organisms have the potential to interact with microplastic (MPs) in the sea, including those who live in the intertidal and tidal zone [3]. Several taxes that have been known to ingest plastics are mussels and oysters that can function as indicator species for MPs contamination [2]. Plastic consumption by the mussels has been widely identified at some places worldwide, such as in England [4], Belgium [5], China [7], [8] and Indonesia [9], [10], [11], [12]. As a consequence, the body tissue of the mussels is severely exposed until they suffer as the effect of consumed MPs [13], [10].

In Indonesia, the study on MPs contamination on the mussels has been conducted at the Northern Coast of Java, particularly in Semarang in 2018. The result of that research showed that $100 \%$ of Anadara granosa had been contaminated with MPs. This indicates the level of risk of MPs intake high in the mussels for human consumption [11]. The other species that are commonly consumed by humans are Mactra sp. and P. viridis. In South Sulawesi, these mussels are common to be found in the coastal area. $P$. viridis is an edible bivalve with enormous cultural potential [14]. One of the well-known places to be found is Sanrobengi Island, Takalar. Sanrobengi is a small island situated in the Western part of Takalar, which is in the border with 
Makassar Bay. The biological diversity is still high around the island. Besides, Sanrobengi Island is one of the destinations for nautical and cultural tourism in Takalar. Some tourism facilities are available such as water transportation and homestay, in order to ease access for the visitors.

In terms of the handling of domestic rubbish, especially plastic, there is still no severe attempt and policy by society and the government. Trash cans are still limited as well as limited of integrated waster disposal, causing the people at the island to throw their rubbish directly in the sea, including the rubbish from the visitors. For that reason, there is a worry for the widening of the distribution and the accumulated microplastic that can be interacted with the muscles and other biotas in the sea surrounding Sanrobengi Island. What is more, there is still no yet research for contaminated microplastic to this kind of mussels conducted in Takalar. So, it is significant to conduct a study to look at the pollution of microplastic the mussels of Perna sp and Meretrix sp, water and sediment at Sanrobengi Island, Takalar.

This study aims goal of this study is to analyze the microplastic abundance in the mussels of Perna viridis and Mactra sp., seawater and sediment at Sanrobengi Island. This study also analyzed the types of plastic polymers found in samples with FTIR methods. This research can contribute data and knowledge in understanding the microplastic distribution in aquatic environments. Also, this research can be a contribution of thought in the handling and prevention of microplastic contaminants in sea waters. It can be additional information for the public about the dangers of microplastic.

\section{MATERIALS AND METHODS}

This study was conducted in Sanrobengi Island, Takalar District, South Sulawesi (Fig. 1). Purposive random sampling technique was carried out on the species of Perna viridis and Mactra sp. with 35 individuals collected respectively. Samples were then added with $10 \% \mathrm{KOH}\left(100 \mathrm{gr} \mathrm{KOH}\right.$ crystal $+1 \mathrm{~L}$ double distilled water) to digest all organic content and incubated at $60^{\circ} \mathrm{C}$ for 24 hours [15]. Mussels samples were further observed visually using a stereomicroscope.

Seawater and sediment samples were collected from triplicate from 4 stations (Fig. 1). Seawater samples were grabbed two times with $30 \mathrm{I}^{-1}$ buckets and poured into nylon mesh sized $330 \mu \mathrm{m}$ with cod-end containing $300 \mathrm{ml}$, also known as the method of neuston net volume reduced [16]. A total of $300 \mathrm{ml}$ filtered water in cod-end were then further subjected to microfiltration using a $0.47 \mu \mathrm{m}$ nitrocellulose filter (Whatman WCN type 7141-104) with the help of a vacuum pump (Rocker 410). Cellulose filters then transferred into a petri dish for visual identification.

Sediments were dried in an oven at $65^{\circ} \mathrm{C}$ overnight for completely dry, followed with sieving, using 5 mm mesh size. Remaining sediments on to bottom $5 \mathrm{~mm}$ were weighed to $100 \mathrm{~g}$ [17], followed by MPs gravity separation $\mathrm{NaCl}(300 \mathrm{~g} \mathrm{NaCL}+11$ aquabidest) with density $1.2 \mathrm{~g} / \mathrm{m} 3$ [18] by stirrer with an electric stirrer for $2 \mathrm{~min}$. Supernatants were gently collected and subjected to cellulose filtration with a vacuum (Rocker 410). Cellulose filters then transferred into a petri dish for visual identification.

All samples are identified visually using stereomicroscope (Euromex SB1902) with 45x magnification. The amount of obtained MPs was calculated according to the type, and pictures were taken and measured by ImageJ software. Microplastic abundance on seawater samples expressed in item $1^{-3}$, MPs abundance on sediment samples expressed in the unit of item kg individual ${ }^{-1}$. While MPs abundance on mussel samples expressed in the unit of item individual ${ }^{-1}$. Microplastic specimens were then subjected to FT-IR (Shimadzu Prestice-21) for polymer identification.

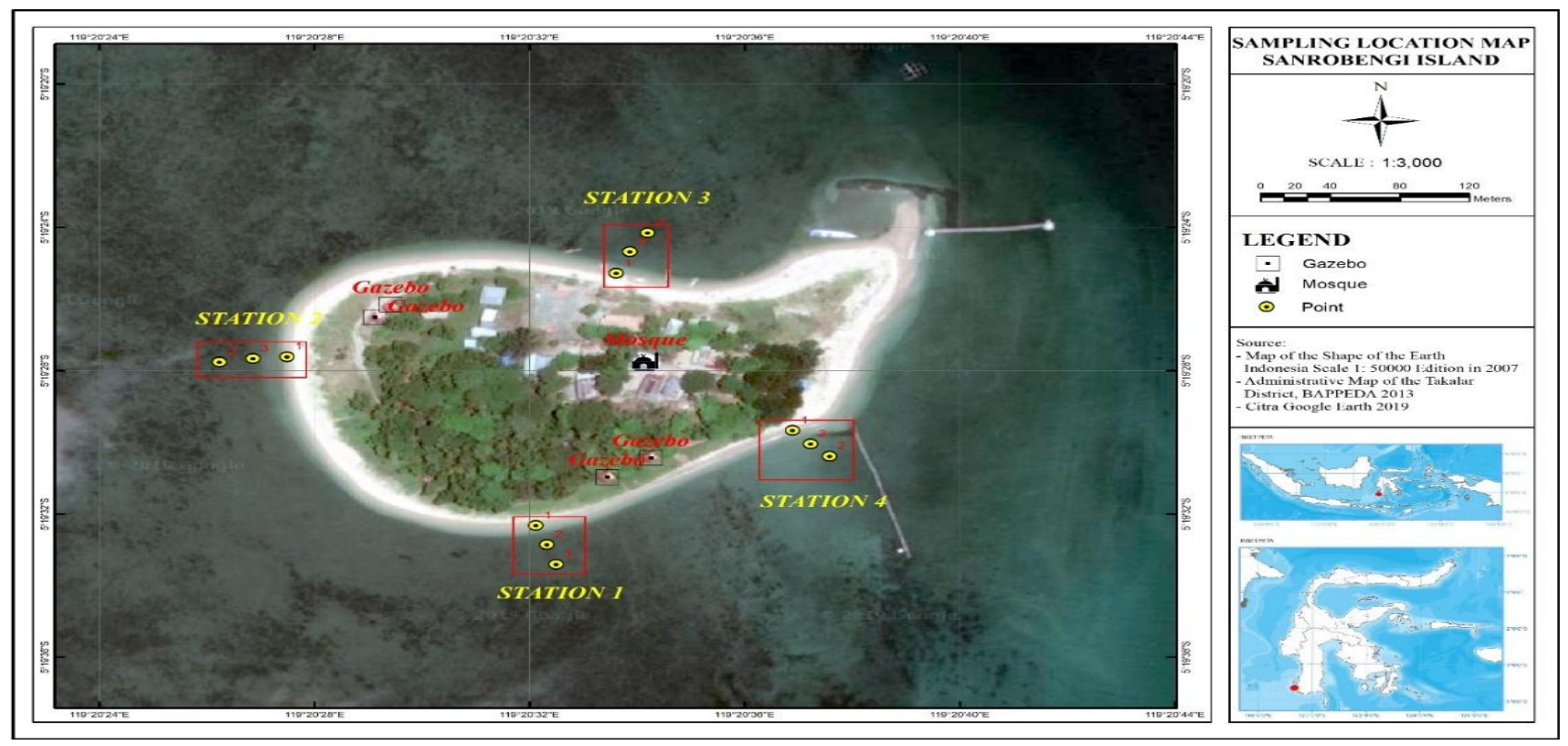

Fig. 1: Sampling location on Sanrobengi Island 


\section{RESULTS}

Laboratory observation on mussel $P$. viridis showed that the mussels are positively contaminated with microplastic (MPs). Of 35 samples identified, $100 \%$ are positively contaminated. Meanwhile, for the mussel Mactra sp., there are 27 (77.14\%) samples contaminated with MPs (Table 1). The average abundance of $P$. viridis contaminated with MPs was $14.62 \pm 1.46$ item individual $^{-}$ ${ }^{1}$, higher than Mactra sp. Where the number of MPs identified was $2.11 \pm 0.29$ item individual $^{-1}$ (Table 1 ).

The amount of microplastic found in seawater was 85 particles with an average of 0.280 item/l. Station 1 has the highest rate of MPs content with an average of $0.433 \pm 0.216$ item $\mathrm{l}^{-1}$ seawater (Fig.2). Meanwhile, for the sediment, there were $203 \mathrm{MPs}$ items observed, with an average abundance of 169.16 item kg${ }^{-1}$ sediment. Station IV has the highest MPs abundance of 193.33 item $\mathrm{kg}^{-1}$ dried sediment (Fig. 2). The average abundance of MPs contaminants found in sediments is higher than in the seawater

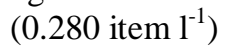

Table 1: Sample and microplastic abundance identified to the mussels at Sanrobengi Island

\begin{tabular}{|c|c|c|c|c|c|}
\hline Species & $\sum$ Sample & Length \pm SE $(\mathbf{c m})$ & Weight \pm SE $(\mathbf{g})$ & $\sum$ Contaminated sample & $\sum$ MPs \\
\hline Mactra sp. & 35 & $2.408 \pm 0.02$ & $2.75 \pm 0.07$ & $27(77.142 \%)$ & 74 \\
\hline P. viridis & 35 & $6.928 \pm 0.24$ & $30.98 \pm 2.08$ & $35(100 \%)$ & 512 \\
\hline
\end{tabular}
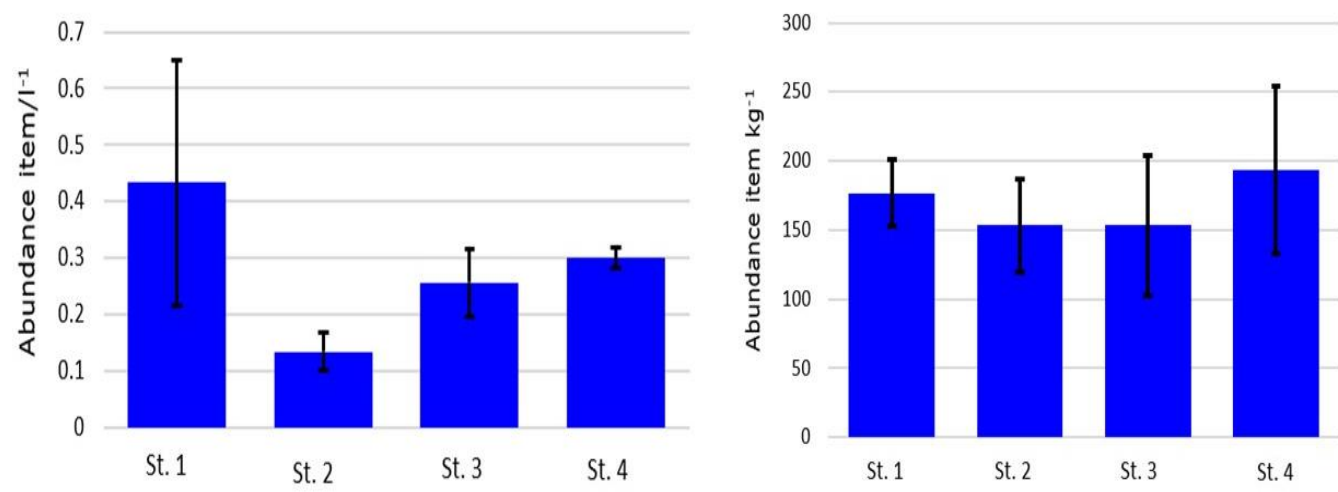

Fig. 2:Microplastic abundance in the seawater (left), sediment (right) at Sanrobengi Island ( $\mathrm{n}=12$ )

\section{Characteristics of microplastic}

The line is the most dominant identified MPs. In the P. viridis, the line was accounted for 99.8\%, while in Mactra sp. and seawater were accounted for $100 \%$, and for the sediment was $99.50 \%$. The abundance of line form of MPs in waters was also mentioned by [2] because the shape and size are thin, which causes the shape of MPs line is more often found in seawater.

In the mussels, seawater, and sediment samples, there are 6 colours of MPs were discovered, i.e., they are transparent, blue, red, black, green, and others (Fig. 3). Blue is the most dominant colour observed, either for the mussels of P. viridis (37\%), Mactra sp. (55\%), seawater (44.71\%) and sediment (63.05\%) (Fig. 3). The size of MPs particles found in the sample varies from 0.084$5 \mathrm{~mm}$, and $0.5-1 \mathrm{~mm}, 1-2.5 \mathrm{~mm}$, and $2.6-5 \mathrm{~mm}$. The size of $1-2.5 \mathrm{~mm}$ is the most current MPs found in P. viridis, Mactra sp., seawater, and sediment (Fig. 3).

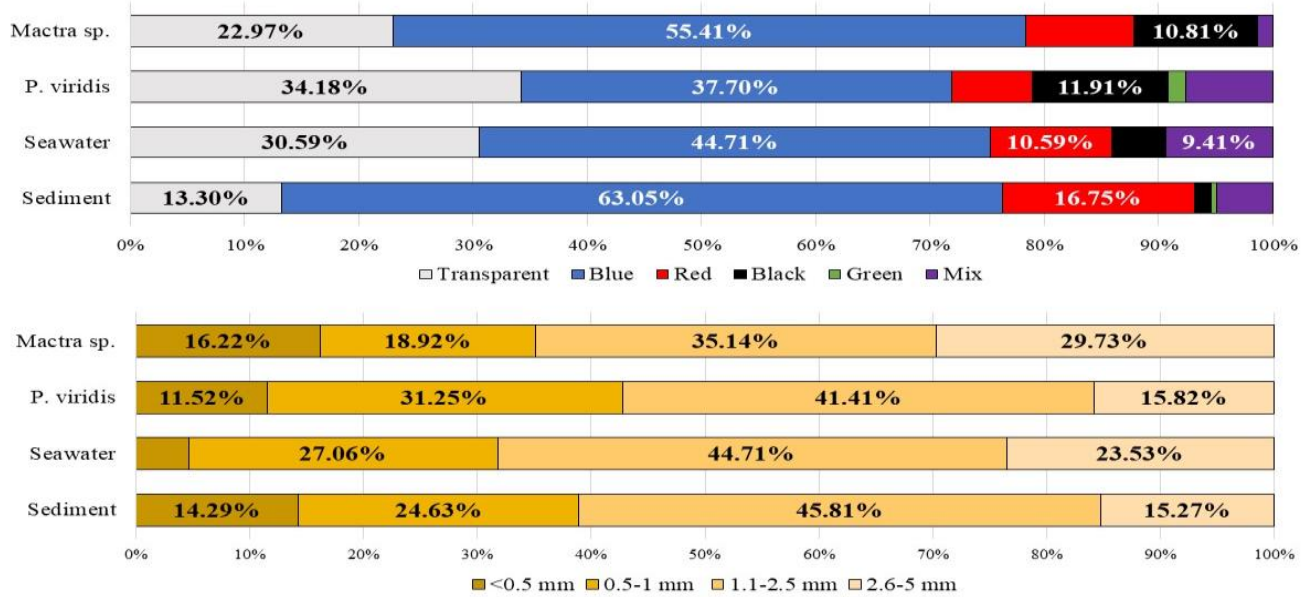

Fig. 3: Colour of microplastic (top) and size (bottom) at Sanrobengi Island ( $\mathrm{n}=74$ for Mactra sp., $\mathrm{n}=512$ for $P$. viridis, $\mathrm{n}=85$ for seawater, $\mathrm{n}=203$ for sediment). 


\section{Microplastic polymer}

FT-IR analysis was performed on the representative samples that have the same morphological characteristics. Based on the results of FT-IR analysis on MPs particles found in the shells of P. viridis and Mactra sp., the most dominant polymer found is Polyethylene terephthalate (PETE). While in seawater and sediment samples, plastic polymer identified as Polyurethane (PU). The presence of PETE polymer in the FTIR interpretation is shown by carbonyl ester $(\mathrm{C}=\mathrm{O})$ with the uptake of around $1700 \mathrm{~cm}$ 1 , which is also supported by the other uptakes as intense aromatic with the uptake of $3093.18 \mathrm{~cm}-1$ and $1514 \mathrm{~cm}-1$ and $1600 \mathrm{~cm}-$ 1 (Fig. 4). Meanwhile, the presence of PU polymer is indicated by the group of amide $(-\mathrm{NH})$ with the uptake of $1647 \mathrm{~cm}-1$, amide II tape with the uptake of approximately $1541.12 \mathrm{~cm}-1$ and amide III tapes $(\mathrm{C}-\mathrm{N})$ with the uptake of about $1338.60 \mathrm{~cm}-1$. Besides, the presence of the aromatic group with the sharp uptake tape of $1541.12 \mathrm{~cm}-1$ and $1647.21 \mathrm{~cm}-1$ ) also indicates the presence of PU group (Fig. 4).
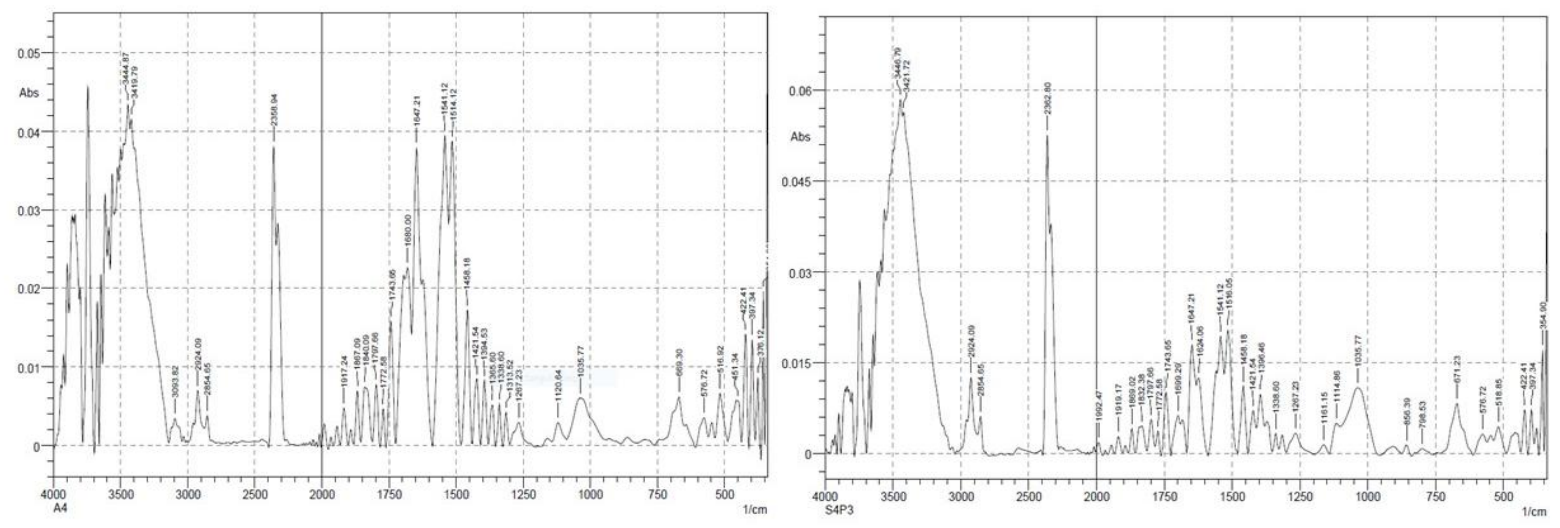

Fig. 4: The result of FTIR in mussel compatible with the wavelength of PETE (left), in the seawater and sediment compatible with the wavelength of PU (right)

\section{DISCUSSION}

The difference amount of the MPs abundance of P. viridis and Mactra sp. can be caused by the size of the mussels, which relatively has a wide difference. The mussels of Mactra sp. Collected in this research has a smaller size than $P$. viridis. The study by Rahim (2019) [10] showed differences in accumulated MPs based on the length of $P$. viridis, where the increase in the mussel size was in line with the amount of MPs found. Furthermore, Alwan (2019) [12], using $P$. viridis of 3, 6, and $9 \mathrm{~cm}$ size, found differences in MPs abundance of 17.45; 19.33 and 21.05 item/g, respectively. Research by Qu et al., (2018) [7] in Chinese Coastal waters found a strong positive linear relationship between MPs in water and P. viridis. All of them indicated that MPs found in mussels could originate from water or sediment of the sea.

In General, the average abundance of microplastics in sediments is indeed large when it is compared to in the seawater or shellfish organisms. The accumulation process causes microplastic contamination of sediments itself. In addition, several types of microplastics have a higher density in seawater. Thus they can stay at the bottom of sediments [19]. The study by Putra (2019) [20] at Bala-Balakang Islands, Mamuju District, West Sulawesi Province was also found differences in MPs abundance between seawater $(1.03 \mathrm{item} / \mathrm{l})$ and sediment $(110.37 \mathrm{item} / \mathrm{kg})$.

Blue is the most dominant colour observed. This is similar to the results of a study conducted by Afdal (2019) [21], finding that blue MPs is the dominant colour found in the Makassar area. Research by Kuhn et al., (2017) [3] found that MPs in water are generally light colour. The size of MPs particle found in the mussel, water and sediment samples varied highly. The most predominant MPs size observed was 1.1-2.5mm). Research by Thushari et al., (2017) [22] states that different invertebrates in coastal ecosystems are more likely to ingest smaller particles or around particle dimensions $(0.01-1 \mathrm{~mm})$ because of their abundant availability easily absorbed. Previously, Syakti et al., (2017) [23] also found MPs abundance in the waters of Cilacap Beach with the most dominant size $<2.5 \mathrm{~mm}(20-46 \%)$.

Polyethene terephthalate is a thermoplastic polyester that is widely used in the manufacture of textile fibre, films, bottles and other printed products [24]. Therefore, PETE polymers found in MPs particles on Sanrobengi Island would possibly be originated from plastic degradation in the form of drink bottles or other types of waste containing PETE polymer. PU is one of the most common polymers, versatile, and widely used globally. That is because the nature of PU which has a high durability with rubber elasticity, which makes it suitable for replacing metals, plastics and rubber in some engineering products [25].

\section{CONCLUSIONS}

Mussel, seawater and sediment in Sanrobengi Island have been contaminated by MPs particles. There is a difference in MPs abundance on P. viridis and Mactra sp. Mussels influenced by habitat size of mussels. It is assumed that the MPs found in 
seawater and sediment might be accumulated in mussels and potentially become a threat to the mussels' sustainability. Moreover, contaminated mussels also can be harmful to food security and human well-being. The high level of contamination found in mussels can be defined as the sign of conducting an immediate effort in proper plastic waste management in Sanrobengi Island.

\section{ACKNOWLEDGEMENT}

Authors thank Robby Nimzet, Muh Afdal, Ega Adhi Wicaksono, Hasrul, Ayu Lestari, Santika, Syeiqido Sora, Jum Eka Rahayu, Kuasa Sari, Muh. Aqsa Jamaludin outstanding support in field and laboratory works.

\section{REFERENCES}

[1] Dewi, S., Agusnar, H., Wirjosentono, B., Halimah, Riza, M., 2015. Synthesis of modified thermoplastic startch (TPS) using in-situ technique.Advances in Environmental Biology, 8 (18): 26-33.

[2] GESAMP, 2019. Guidelines for the monitoring and assessment of plastic litter in the ocean.Journal Series GESAMP Reports and Studies, No. 99, 130p.

[3] Kühn, S., van Werven, B., van Oyen, A., Meijboom, A., Bravo Rebolledo, E. L., \& van Franeker, J. A., 2017. The use of potassium hydroxide $(\mathrm{KOH})$ solution as a suitable approach to isolate plastics ingested by marine organisms. Marine Pollution Bulletin, 115(1-2):86-90.

[4] Li, J. N., X. Y. Qu, L. Su, W. W. Zhang, D. Q. Yang, P. Kolandhasamy, D. J. Li and H. H. Shi, 2016. Microplastics in mussels along the coastal waters of China.Environmental Pollution, 214: 177-184.

[5] Browne, M. A., Dissanayake, A., Galloway, T. S., Lowe, D. M., \& Thompson, R. C., 2008. Ingested Microscopic Plastic Translocates to the Circulatory System of the Mussel,Mytilus edulis(L.).Environmental Science \& Technology, 42(13):5026-5031.

[6] De Witte, B., Devriese, L., Bekaert, K., Hoffman, S., Vandermeersch, G., Cooreman, K., \& Robbens, J, 2014. Quality assessment of the blue mussel (Mytilus edulis): Comparison between commercial and wild types.Marine Pollution Bulletin, 85(1): 146-155.

[7] Qu, X., Su, L., Li, H., Liang, M., \& Shi, H., 2018. Assessing the relationship between the abundance and properties of microplastics in water and in mussels.Science of The Total Environment, 621: 679-686.

[8] Kolandhasamy, P., Su, L., Li, J., Qu, X., Jabeen, K., \& Shi, H, 2018. Adherence of microplastics to soft tissue of mussels: A novel way to uptake microplastics beyond ingestion. Science of The Total Environment, 610-611:635-640.

[9] Sari, K, 2018. The Existence of Microplastics in Filter Feeder Animals in Padang Seagrass, Spermonde Islands, Makassar City. Undergraduate Thesis. Departement of Marine Sciences. Hasanuddin University. [in Indonesian]

[10] Rahim, N. F., 2019. The impact of microplastic accumulation on various shell length sizes on some Perna viridis green shell organs. Master Thesis. Departement of Fisheries, Faculty of Marine Sciences and Fisheries. Universitas Hasanuddin. [in Indonesian]

[11] Widianarko, B. dan Inneke Hantoro, 2018. Microplastic in seafood from the north coast of Java. Soegijapranata Catholic University. Semarang. ISBN 978-602-6865-74-8. [in Indonesian]

[12] Alwan, A., 2019. microplastic content in fisheries commodities and the environment in Sayung Beach, Demak. Undergraduate Thesis. Faculty of Mathematics and Natural Sciences, Universitas Diponegoro. Semarang. [in Indonesian]

[13] Avio, C. G., Gorbi, S., \& Regoli, F., 2017. Plastics and microplastics in the oceans: From emerging pollutants to emerged threat.Marine Environmental Research. 128:2-11.

[14] Soon, T. K. and Ransangan, J., 2015. Factors influence the larvae distribution and spat settlement Marudu Bay, Sabah, Malaysia.Advances in Environmental Biology, 9(17): 18-23.

[15] Rochman, C.M., Tahir, A., Williams, S.L., Baxa, D. V., Lam, R., Miller, J.T., Teh, F.C., Werorilangi, S., Teh, S.J., 2015. Anthropogenic debris in seafood: Plastic debris and fibers from textiles in fish and bivalves sold for human consumption.Scientific Reports, 5(1).

[16] Covernton, G. A., Pearce, C. M., Gurney-Smith, H. J., Chastain, S. G., Ross, P. S., Dower, J. F., \& Dudas, S. E., 2019. Size and shape matter: A preliminary analysis of microplastic sampling technique in seawater studies with implications for ecological risk assessment.Science of The Total Environment, 667:124-132.

[17] Hidalgo-Ruz, V., Gutow, L., Thompson, R. C., \& Thiel, M., 2012. Microplastics in the marine environment: A review of the methods used for identification and quantification. Environmental Science \& Technology, 46(6): 3060-3075.

[18] Food and Agriculture Organization of The United Nations, 2017. Microplastic in fisheries and aquaculture. ISBN: 978-92-5109882-0.

[19] Shim, W. J., Hong, S. H., \& Eo, S., 2018. Marine microplastics: Abundance, distribution, and composition. Microplastic Contamination in Aquatic Environments.Elsevier, 1-26.

[20] Putra, T.P., 2019. Microplastic pollution studies on fish, water and sediment in the Bala-Balakang Archipelago, Mamuju District, West Sulawesi. Master Thesis. Environmental Management Study Program of Graduate School. Universitas Hasanuddin. [in Indonesian]

[21] Afdal, M., 2019. Study of microplastic abundance in the coastal waters of Makassar City. Master Thesis. Integrated Coastal Resource Management. Universitas Hasanuddin. [in Indonesian] 
[22] Thushari, G. G. N., Senevirathna, J. D. M., Yakupitiyage, A., \& Chavanich, S., 2017. Effects of microplastics on sessile invertebrates in the eastern coast of Thailand: An approach to coastal zone conservation.Marine Pollution Bulletin, 124(1):349-355.

[23] Syakti, D.A., Bouhroum, R., Hidayati, V.N., Koenawan, J.C., Boulkamh, A., et al., 2017. Beach macro-litter monitoring and floating microplastic in a coastal area of Indonesia.Marine Pollution Bulletin, 122(1-2): 217-225.

[24] Gupta, V. B., \& Bashir, Z., 2005. PET fibers, films, and bottles: Sections 5-7. Handbook of Thermoplastic Polyesters, 362388.

[25] Akindoyo, J. O., Beg, M. D. H., Ghazali, S., Islam, M. R., Jeyaratnam, N., \& Yuvaraj, A. R., 2016. Polyurethane types, synthesis and applications-a review.RSC Advances, 6(115): 114453-114482. 